\title{
Polyphenoloxidase and peroxidase in avocado pulp (Persea americana Mill.)
}

\author{
Polifenoloxidase e peroxidase na polpa de abacate (Persea americana Mill.)
}

\author{
Lucimara Salvat VANINI ${ }^{1}$, Angela KWIATKOWSKI ${ }^{1}$, Edmar CLEMENTE ${ }^{1 *}$
}

\begin{abstract}
The aim of the present investigation was to evaluate the enzymatic activity of polyphenoloxidase and peroxidase in avocado pulps, from the Northwest area of Paraná-Brazil, in order to compare the varieties on their enzymatic activity for both, minimum and industrial processing. Enzymatic extracts were prepared from avocado pulp of Choquete, Fortuna and Quintal varieties, in green and ripe maturation stage. Thermal treatment was applied with temperatures $60,65,70,75$ and $80^{\circ} \mathrm{C}$. The enzymatic activities were determined by using spectrophotometer. A decline of polyphenoloxidase activity was observed in all of the varieties when both, temperature and time increased. Total inactivation of enzymes was not observed in the largest temperature. Fortuna and Choquete variety showed the lowest polyphenoloxidase activity in the ripe stage. Soluble peroxidase showed activity in the green stage, whereas, ionically bound peroxidase activity increased with the change from green to ripe maturation stage in Choquete variety.

Keywords: Persea americana Mill.; enzymes; temperature; maturation stage.
\end{abstract}

\section{Resumo}

O objetivo foi avaliar a atividade enzimática da polifenoloxidase (PPO) e da peroxidase (POD) em polpas de abacates, da região Noroeste do Paraná, Brasil, visando comparar as variedades e suas atividades enzimáticas para processamento mínimo ou industrial. Extratos enzimáticos foram preparados da polpa de abacate das variedades Choquete, Fortuna e Quintal no estágio de maturação verde e maduro. Foi aplicado tratamento térmico com temperaturas de $60,65,70,75$ e $80^{\circ} \mathrm{C}$. As atividades enzimáticas foram determinadas por espectrofotometria. Observou-se declínio da atividade da PPO, à medida que aumentava a temperatura e o tempo em todas as variedades. Não foi observada inativação total das enzimas na maior temperatura. As variedades Fortuna e Choquete apresentaram menor atividade da PPO no estágio maduro. A POD solúvel apresentou menor atividade no estágio verde, e, atividade da POD ionicamente ligada aumentou com a mudança do estágio verde para maduro para a variedade Choquete.

Palavras-chave: Persea americana Mill.; enzimas; temperatura; estagios de maturação.

\section{Introduction}

The avocado tree (Persea americana Mill.) is cultivated almost all tropical and subtropical areas. It is one of the most fruitful productive plants per unit of cultivated area (TANGO; TURATTI, 1992; MEDINA et al., 1998). The Brazilian production in 2007 was 154,096 tons (BRASIL, 2007).

The sensorial qualities, the nutritional value, and the large amount of vitamins of the avocado justify the expansion of the fruit consumption. The nutritional value of avocado is due to its high lipidic (8.4\%) and proteic (1.2\%) contents, which may reach $30 \%$ of its pulp. Due to its chemical composition it also becomes appropriate for industrial purposes (CANTO; SANTOS; TRAVAGLIN, 1980; TANGO; CARVALHO; SOARES, 2004).

Enzymatic reaction is relevant in food because the formation of highly desirable compounds depends on enzymatic reactions but, on the other hand, some undesirable compounds may derive from them. Such reactions occur in food 'in natura', during maturation stages, processing, and storage (WEEMAES et al.,
1998). Polyphenoloxidase (PPO) and peroxidase (POD) enzymes are among the major chemical components that cause changes during the maturation of fruits influencing the final quality of vegetable products (THÉ et al., 2001).

PPO and POD enzymes have been detected in many fruits and vegetables. The actions of these enzymes are connected to the enzymatic darkening and 'loss of flavor' (GOMES et al., 2001; VALDERRAMA; CLEMENTE, 2004).

There are several studies describing the POD action on substances that produce live colors in oxidation, but such action can cause a great variety of biodegradating reactions, and thus it has a versatility is so high that is not supplanted by any other enzyme. In general, it is accepted that POD, unlike other enzymes, are not inactivated by heat (CLEMENTE, 1998; LUIZ; HIRATA; CLEMENTE, 2007). Therefore, POD activity is used in many food industries as a whitening index or value (HALPIN et al., 1989). POD inactivation in plant

Recebido para publicação em 20/8/2008

Aceito para publicação em 8/7/2009 (003807)

${ }^{1}$ Laboratory of Food Biochemistry, Chemistry Department, State University of Maringá - UEM, Av. Colombo, Zona 07, CEP 87020-900, PO Box 5790, Maringá - Paraná, Brazil,E-mail:eclemente@uem.br

${ }^{*}$ A quem a correspondência deve ser enviada 
extract is usually non-linear relationship regarding time versus temperature, which occurs, probably, due to the presence of isoperoxidase with different stabilities in relation to temperature (WEEMAES et al., 1998).

When smashed, cut or triturated, most of fruit pulps become dark quickly. Such a discoloration originates from reactions catalyzed by PPO enzyme (ARAÚJO, 1999). This enzyme possesses copper $\left(\mathrm{Cu}^{++}\right)$in the active nucleus, and it works as a mixed-function-oxidase catalyzing two different types of reaction. The first reaction, monoxigenase, acts in the hydroxylation from monophenols to dihydroxiphenols; the second one, oxidase, leads to the oxidation from diphenols into o-chinones (PINELI; MORETTI, 2007).

Regarding the avocado pulp, the application of thermal treatment can cause adverse effects, such as changes in color and flavor and loss of vitamins (SOLIVA-FORTUNY et al., 2002). Due to these reactions and some others, the temperature used must be controlled in the post-harvest, that is, after the picking up process (LUIZ et al., 2007). In the food industry, the enzymatic inactivation is one of the resources used in the processing of several products. That process aims at conserving or preserving the product in the processing period and also during storage (CLEMENTE; PASTORE, 1998).

Those two enzymes, which are present in avocados, are studied firstly aiming at clarifying the ambiguity of results, and then, for leading to future understanding of the performance of that enzyme in the fruit ripening process.

The incorporation of avocado paste or pulp to meat derived products is an alternative to enrich the nutrition value of those products. Rueda-Lugo, Gonzáles-Tenório and Totosaus (2006) evaluated the substitution of the animal fat for avocado pulp paste, which is rich in vegetable oil, aiming at improving the nutritional value of hotdog sausages.

Based on those definitions, the main objective of the present study is to characterize the activity of polyphenoloxidase enzyme (PPO) extracted from the pulp of avocados belonging to Fortuna, Quintal, and Choquete varieties and the peroxidase (POD) soluble fractions and ionically bound to avocado pulp from Choquete variety to check which variety has the lowest activity of those enzymes in the 'post-harvest' period, in green and ripe maturation stages. The main purpose is the use of the fruit pulp in the elaboration of a minimally processed and/or industrialized product.

\section{Materials and methods}

Avocados of Persea americana Mill. species, in green and ripe maturation stages, belonging to Fortuna, Quintal, and Choquete varieties were selected from the Experimental Farm of the Regional Campus in the city of Diamante do Norte, which belongs to the State University of Maringá - UEM, located in the Northwest area of Paraná-Brazil at 362,000 $\mathrm{m}$ above the sea level, $22^{\circ} 63^{\prime} 94^{\prime \prime}$ latitude, and $52^{\circ} 89^{\prime} 01^{\prime \prime}$ longitude. The fruits were taken to the Laboratory of Food Biochemistry of the
University - UEM. The fruits were washed, sanitized, and cut longitudinally to remove the pulp. All chemical reagents used were of analytical degree.

\subsection{Obtaining the enzymatic extracts of avocado pulp at different $\mathrm{pHs}$}

For the preparation of the raw extract of avocado pulp, $30 \mathrm{~g}$ of fruit pulp was used. The pulp was homogenized with $50 \mathrm{~mL}$ of sodium phosphate buffer, at different $\mathrm{pHs}(6.0,6.5,7.0$, and 7.5) for two minutes in a blender. Later, the mixture was filtered in a cotton fabric. The filtrate was centrifuged at $12.000 \mathrm{rpm}$ at $40{ }^{\circ} \mathrm{C}$, for 20 minutes. The supernatant was stocked at $-18{ }^{\circ} \mathrm{C}$ to determine the enzymatic activity subsequently.

\subsection{Obtaining raw extracts from $P O D$ and PPO enzymes}

For the preparation of raw extracts from PPO enzyme, $150 \mathrm{~g}$ of pulp of Quintal, Fortuna, and Choquete avocado varieties in two different maturation stages (green and ripe) were weighed. For the preparation of the POD extract, $150 \mathrm{~g}$ of avocado pulp of Choquete variety was used; the pulp was homogenized with $300 \mathrm{~mL}$ of phosphate buffer solution (100 mM, pH 6.0); $300 \mathrm{~mL}$ of buffer phosphate solution was used (100 mM, pH 7.4) for extracting the PPO. After obtaining the supernatants, they were stored at $-18{ }^{\circ} \mathrm{C}$. The residue of the homogenized centrifugation was resuspended aiming at obtaining the ionically bound POD fraction by using $30 \mathrm{~mL}$ of $\mathrm{NaCl}$ solution in sodium phosphate buffer $(100 \mathrm{mM}, \mathrm{pH} 6.0)$. The mixture was then centrifuged at $12.000 \mathrm{rpm}$, at $40^{\circ} \mathrm{C}$, for 20 minutes. Later, the enzymatic extracts were stored at $-18^{\circ} \mathrm{C}$.

\subsection{Determining PPO and POD enzymatic activity}

The activity of the PPO enzyme was determined according to Fujita et al. (1995). $0.5 \mathrm{~mL}$ of PPO extract with $0.8 \mathrm{~mL}$ of buffer solution of $100 \mathrm{mM}$ sodium phosphate and $0.05 \mathrm{~mL}$ of $0.01 \mathrm{M}$ solution of catechol were mixed. The resulting mixture was incubated at $30{ }^{\circ} \mathrm{C}$ for 30 minutes. Next, $0.8 \mathrm{~mL}$ of $2 \mathrm{M}$ perchloric acid was added and placed in an ice bath. The activity of PPO was determined by measuring the absorbance using a spectrophotometer $(\lambda=395 \mathrm{~nm})$. One unit of PPO activity was defined as the increase of one unit of absorbance/minute. $\mathrm{mL}^{-1}$ of sample.

The POD activity was determined according to the method described by Clemente (1998). $0.2 \mathrm{~mL}$ of the sample, $2.7 \mathrm{~mL}$ of $0.1 \%$ solution of $\mathrm{H}_{2} \mathrm{O}_{2}$ in sodium phosphate buffer $(100 \mathrm{mM}, \mathrm{pH}$ 6.0 ), and $0.1 \mathrm{~mL}$ of alcoholic solution of ortho - dianisidine $1.0 \%$ were then mixed with the extracts. The reading was performed at $\lambda=460 \mathrm{~nm}$. The unit of activity of POD was defined as the increase of a unit of absorbance per minute $\mathrm{mL}^{-1}$ of sample.

\subsection{Thermal treatment}

The enzymatic extracts from the three varieties in different maturation stages were submitted to thermal treatment in temperatures of $60,65,70,75$, and $80^{\circ} \mathrm{C}$ for periods from 1 to 
10 minutes, and, the activities of PPO and POD enzymes were determined as described in 2.3 .

\section{Results and discussion}

The results of the $\mathrm{pH}$ evaluation indexes for the extraction of enzymes are shown in Figure 1. The highest activity of PPO enzyme was observed at $\mathrm{pH} 7.4$; whereas the highest POD enzymatic activity was found at $\mathrm{pH}$ 6.0. After determining the respective enzymes, buffer solutions were used at the $\mathrm{pH}$ values found for each one of the enzymatic extracts in order to observe the enzymatic activity in the pulp of different avocado varieties, in both green and ripe maturation stages.

According to Brecht et al. (2007), fruits that have $\mathrm{pH}$ lower than 4.5 present low PPO activity. Thus, most of the chemical products used to inhibit enzyme darkening has acidifiers in their composition.

In Table 1, the values of PPO enzymatic activity are presented for the three avocado varieties, that is, Quintal, Fortuna, and Choquete in both green and ripe maturation stages. It is observed that PPO initial activity increased as the
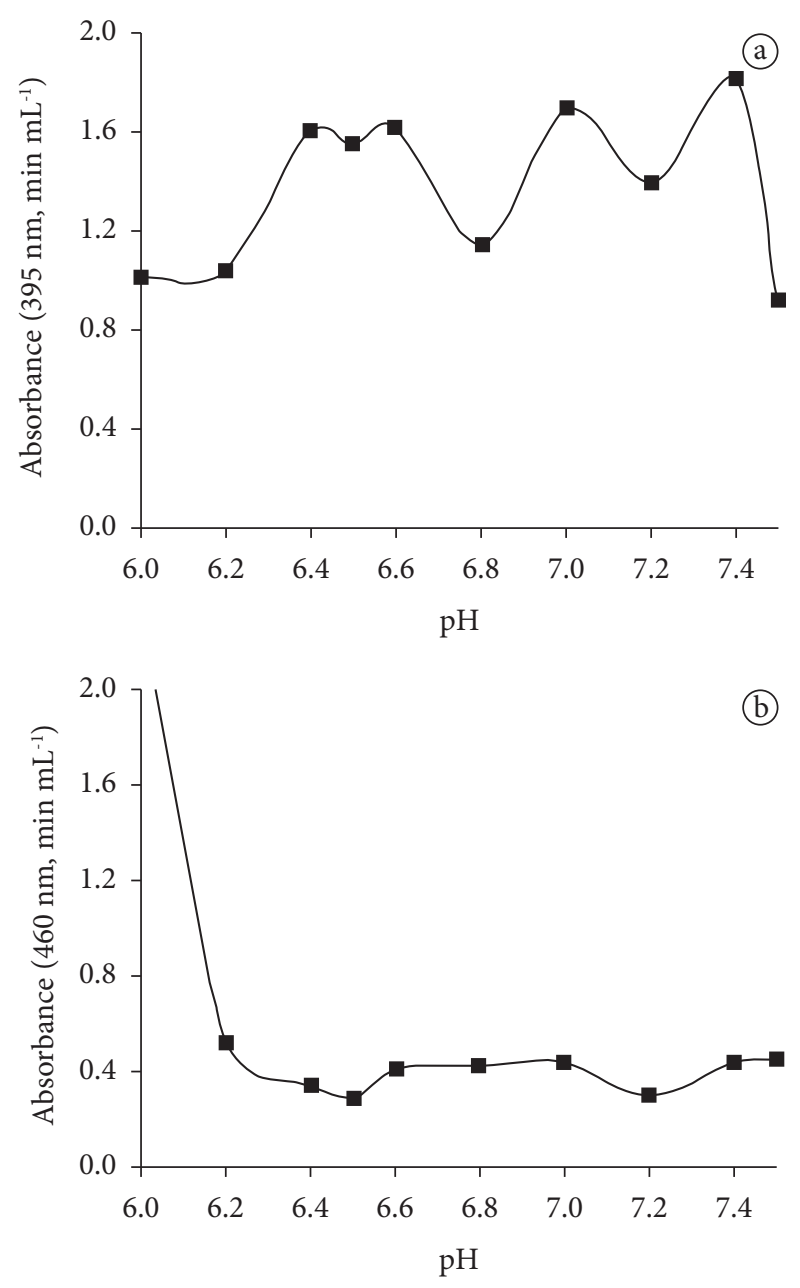

Figure 1. Enzymatic activity at different $\mathrm{pH}$ indexes in avocado pulp: a) PPO; b)POD. fruit reached the ripening stage, except for the Choquete variety. It can be observed that the PPO enzymatic activity varied according to the avocado variety tested. The fruit maturation stage has also influenced the activity of the PPO enzyme. The pulp of the Choquete avocado variety presented the highest PPO enzymatic activity in the green maturation stage. However, in the ripening stage, the higher activity of that enzyme was present in the pulp of Quintal avocado variety. The activity of that enzyme was higher in the ripening stage of the pulp of Quintal and Fortuna varieties. With respect to the pulp of Choquete variety, it was observed that the PPO activity was higher in the green stage.

The variations of enzymatic activity, in different maturation stages, can be an indicator of the involvement of that enzyme in the last maturation stages of the fruit development (ROBINSON, 1991). The variations in PPO activity derive from the diversity of fruit varieties, fruit maturity, cultivation conditions, and fruit post-harvest condition (FENEMA, 1998).

For the analysis of PPO enzymatic activity, in the avocado pulps analyzed, an inverse relationship can be observed between the temperature and the time of necessary heating for enzyme inactivation. According to Weemaes et al. (1998), the thermal treatment is the most effective for PPO inactivation.

The Fortuna variety, in the stage of green maturation, presented the lowest index of activity of PPO enzyme in time 'zero' at temperature of $60{ }^{\circ} \mathrm{C}$. With the increase in time and temperature, it can be observed that the index of enzymatic activity of the avocado pulp extracted from that variety remains the lowest. In the ripe stage, Choquete and Fortuna varieties were presented the lowest indexes of that activity, at $60{ }^{\circ} \mathrm{C}$ initially. With the increase in temperature, and the contact time between pulp extracts, it can be observed that the Choquete variety presents the lowest value of enzymatic activity. Weemaes et al. (1998) studied the thermo stability of PPO enzyme in several fruits and reported that avocado is a fruit that possesses high PPO activity. In their results, they observed that the inactivation of PPO enzyme, in avocado with commercial maturity, began at a temperature from 60 to $65^{\circ} \mathrm{C}$.

The residual PPO activity (\%) in the pulp of Quintal, Fortuna, and Choquete varieties in the two maturation stages (green and ripe) are shown in Figure 2.

In the present investigation, the total inactivation of PPO enzyme did not occur with the increase in the different temperatures used in a time period from 1 to 10 minutes. This fact can be explained by the presence of thermo-resistant isoenzymes, and it is necessary to perform the isolation of such enzymes to carry out a study showing that behavior before thermal treatments.

Figure 2 shows that the larger the temperature and the time applied in the process, the smaller is the percentage (\%) of that activity in the avocado pulp of the three varieties under study, thus proving the effect of the temperature on the contact time necessary for the thermal inactivation of the product. 
Table 1. Enzymatic activity of PPO of Quintal, Choquete, and Fortuna variety in both green and ripe maturation stages, at different temperatures (T) $\left(\mathrm{n}=3^{\star}\right)$

\begin{tabular}{|c|c|c|c|c|c|c|c|c|c|c|c|}
\hline \multirow{2}{*}{$\begin{array}{l}\text { Enzymatic extract } \\
\text { of avocado pulp }\end{array}$} & $\mathrm{T}\left({ }^{\circ} \mathrm{C}\right)$ & 60 & 65 & 70 & 75 & 80 & & 65 & 70 & 75 & 80 \\
\hline & Time (minute) & \multicolumn{10}{|c|}{ Enzymatic activity $\left(\Delta \mathrm{DO}_{395 \mathrm{~nm} \text { minute.mL }}{ }^{-1}\right)$} \\
\hline & & \multicolumn{5}{|c|}{ Green stage } & \multicolumn{5}{|c|}{ Ripe stage } \\
\hline \multirow[t]{9}{*}{ Quintal } & 0 & 2.579 & 2.579 & 2.579 & 2.579 & 2.579 & 2.955 & 2.955 & 2.955 & 2.955 & 2.955 \\
\hline & 1 & 2.499 & 2.562 & 2.361 & 2.190 & 2.189 & 2.760 & 2.824 & 2.575 & 2.344 & 2.252 \\
\hline & 2 & 2.433 & 2.483 & 2.255 & 2.133 & 2.149 & 2.621 & 2.770 & 2.520 & 2.278 & 2.168 \\
\hline & 3 & 2.423 & 2.460 & 2.210 & 2.106 & 2.052 & 2.547 & 2.561 & 2.430 & 2.174 & 2.156 \\
\hline & 6 & 2.273 & 2.177 & 1.923 & 1.735 & 1.452 & 2.277 & 2.334 & 2.205 & 1.998 & 1.656 \\
\hline & 7 & 2.230 & 2.160 & 1.871 & 1.694 & 1.331 & 2.283 & 2.298 & 2.128 & 1.923 & 1.544 \\
\hline & 8 & 2.173 & 2.150 & 1.800 & 1.575 & 1.211 & 2.211 & 2.203 & 2.113 & 1.850 & 1.472 \\
\hline & 9 & 2.118 & 2.100 & 1.783 & 1.435 & 1.135 & 2.198 & 2.121 & 2.040 & 1.806 & 1.356 \\
\hline & 10 & 2.079 & 2.060 & 1.660 & 1.306 & 1.099 & 2.186 & 2.019 & 2.000 & 1.782 & 1.298 \\
\hline \multirow{9}{*}{ Choquete } & 2 & 3.677 & 3.679 & 3.408 & 2.992 & 2.790 & 2.312 & 2.010 & 1.976 & 1.919 & 1.708 \\
\hline & 3 & 3.534 & 3.447 & 3.300 & 2.825 & 2.594 & 2.300 & 1.960 & 1.927 & 1.872 & 1.606 \\
\hline & 4 & 3.497 & 3.367 & 3.133 & 2.705 & 2.400 & 2.208 & 1.932 & 1.851 & 1.883 & 1.532 \\
\hline & 5 & 3.423 & 3.084 & 3.009 & 2.655 & 2.393 & 2.098 & 1.920 & 1.738 & 1.709 & 1.418 \\
\hline & 6 & 3.271 & 2.811 & 2.829 & 2.534 & 2.231 & 1.964 & 1.890 & 1.678 & 1.634 & 1.378 \\
\hline & 7 & 2.969 & 2.757 & 2.763 & 2.499 & 2.133 & 1.824 & 1.861 & 1.670 & 1.600 & 1.246 \\
\hline & 8 & 2.878 & 2.649 & 2.743 & 2.394 & 2.120 & 1.835 & 1.752 & 1.558 & 1.616 & 1.176 \\
\hline & 9 & 2.963 & 2.567 & 2.621 & 2.387 & 2.080 & 1.800 & 1.735 & 1.540 & 1.526 & 1.172 \\
\hline & 10 & 2.876 & 2.569 & 2.515 & 2.294 & 2.005 & 1.726 & 1.684 & 1.541 & 1.481 & 1.082 \\
\hline \multirow[t]{4}{*}{ Fortuna } & 0 & 2.130 & 2.130 & 2.130 & 2.130 & 2.130 & 2.404 & 2.404 & 2.404 & 2.404 & 2.404 \\
\hline & 8 & 1.690 & 1.631 & 1.559 & 1.462 & 1.300 & 2.018 & 1.794 & 1.592 & 1.500 & 1.418 \\
\hline & 9 & 1.621 & 1.598 & 1.530 & 1.377 & 1.279 & 2.000 & 1.615 & 1.511 & 1.478 & 1.328 \\
\hline & 10 & 1.599 & 1.535 & 1.511 & 1.320 & 1.151 & 1.888 & 1.612 & 1.465 & 1.414 & 1.216 \\
\hline
\end{tabular}

${ }^{\star} \mathrm{n}=$ replication number.

The PPO enzyme is related with the pulp darkening. Thus, a treatment to reduce its activity is a positive alternative to be used in industrial processing.

In Table 2, the values of enzymatic activity of soluble ionically bound POD and POD are shown, for the pulp of Choquete variety in both green and ripe maturation stages.

It may be observed that the activity of POD soluble enzyme decreases with the maturation of the fruit and with the increase in temperature and time. The POD soluble enzyme activity is related to the process of avocado ripening (MURASAKI, 2005) influencing the change in the fruit flavor, therefore, any treatment capable of reducing this activity will help further studies on industrialization.

Ionically bound POD activity increases with the change in the maturation stage, but it reduces with the increase in temperature and time. It can be observed that it was smallest in the initial activity of the green stage than in the ripe stage.

Figure 3 shows the residual activity of POD (\%) in avocado pulp belonging to the Choquete variety. The ionically bound POD activity in the Choquete variety remains active even after the application of the thermal treatment at $80^{\circ} \mathrm{C}$ for 10 minutes and a loss of approximately $60 \%$ of its activity in the fruit green stage and $50 \%$ in the ripe stage. 

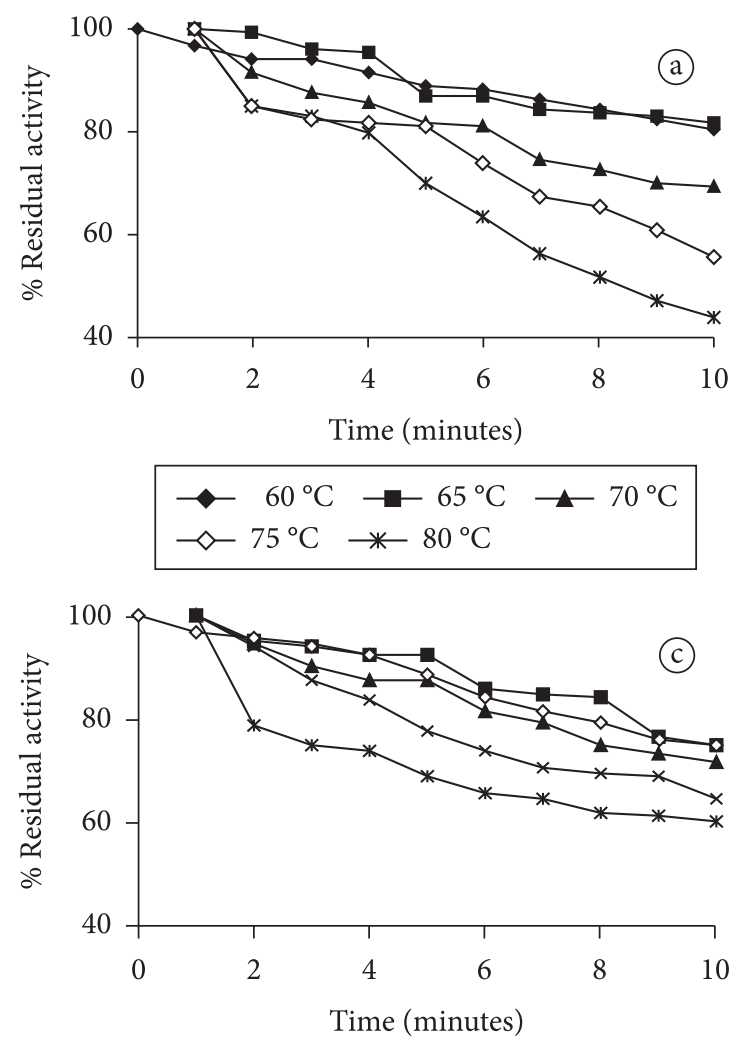

$$
\begin{aligned}
& \checkmark 60^{\circ} \mathrm{C} \rightarrow 65^{\circ} \mathrm{C} \rightarrow 70^{\circ} \mathrm{C} \\
& \times-75^{\circ} \mathrm{C} \rightarrow-40^{\circ} \mathrm{C}
\end{aligned}
$$

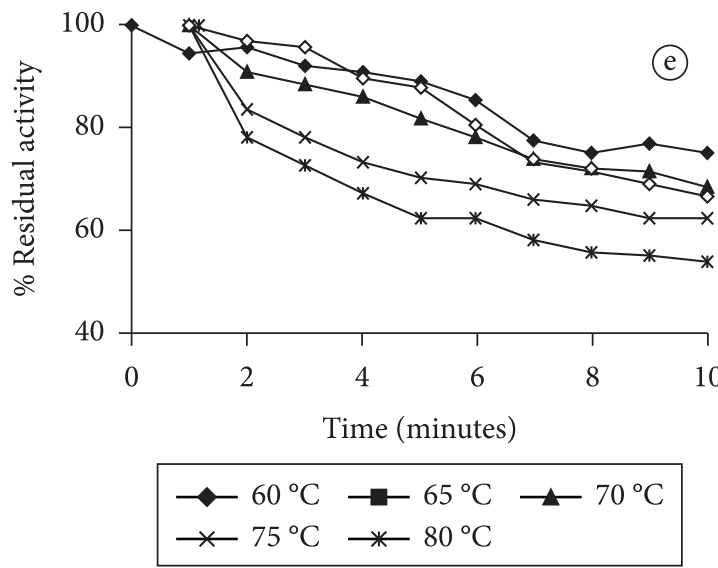

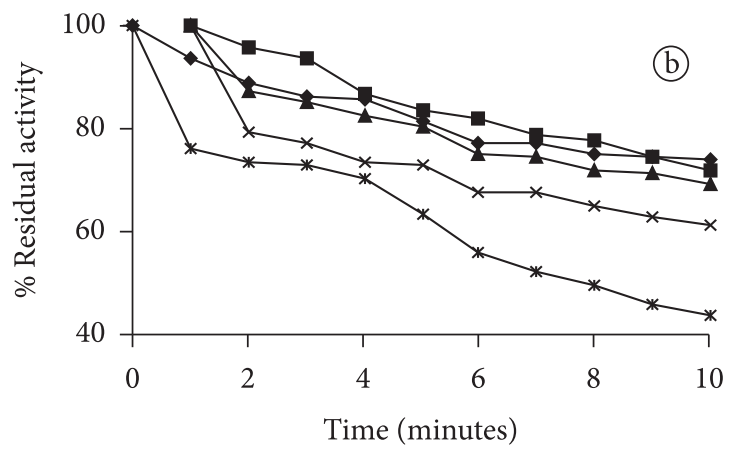

$\multimap 60^{\circ} \mathrm{C} \rightarrow 65^{\circ} \mathrm{C} \rightarrow 70^{\circ} \mathrm{C}$
$\times-75^{\circ} \mathrm{C} \rightarrow 80^{\circ} \mathrm{C}$
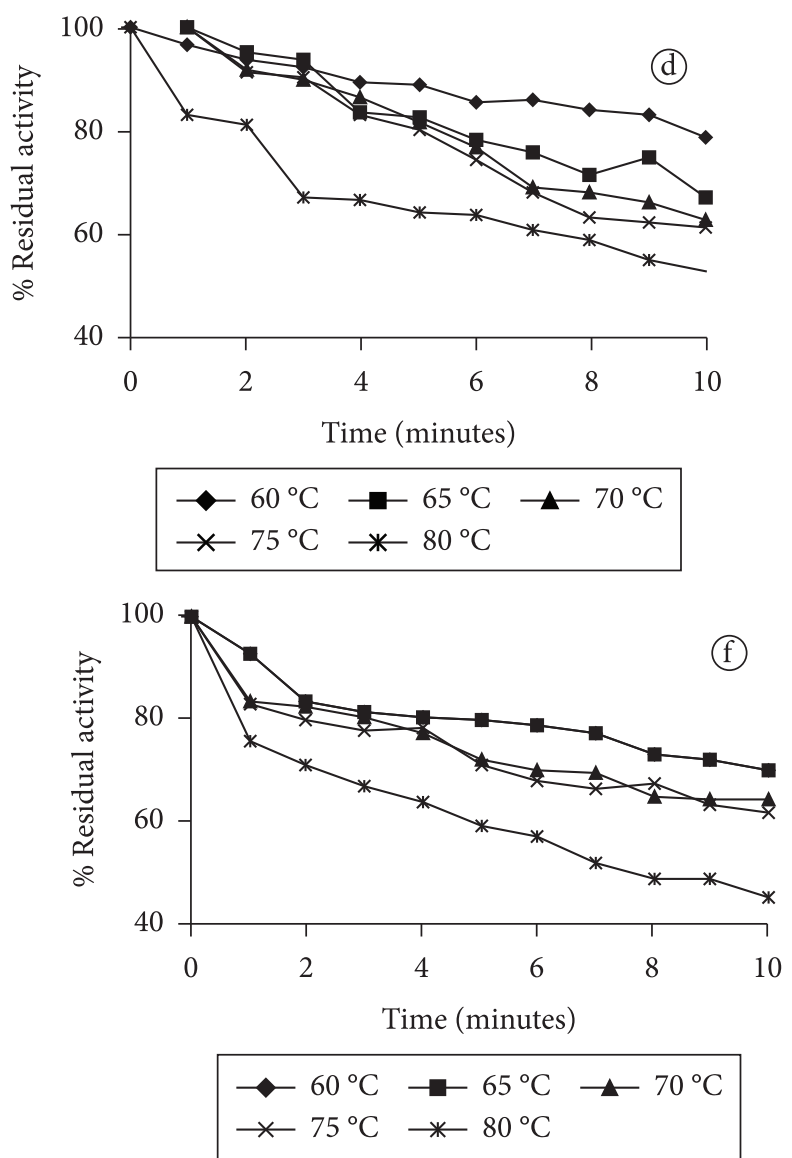

Figure 2. PPO $\left(\triangle \mathrm{DO}_{395 \mathrm{~nm} \mathrm{min.mL^{-1 }}}\right)$ residual activity of varieties/maturation stages: a) Quintal/green stage, b) Quintal/ripe stage, c) Fortuna/green stage, d) Fortuna/ripe stage, e) Choquete/green stage, and f) Choquete/ripe stage.

Figure 4 presents the values of the residual activity (\%) of ionically bound POD. It can be observed that that activity remains active after thermal treatment at $80^{\circ} \mathrm{C}$ and 10 minutes-time.

The ionically bound POD activity in the Choquete variety also remains active even after the application of the thermal treatment at $80{ }^{\circ} \mathrm{C}$ after 10 minutes and loss of approximately of $60 \%$ of its activity in the green stage and $50 \%$ in the ripe stage. Comparing the activity of soluble POD with ionically bound POD, in the two maturation stages, it is observed that the ionic fraction presented higher activity than that of the soluble fraction.

The use of temperatures higher than those used in the present study is not recommended for avocado pulp because they can destroy the sensorial properties of the pulp, mainly flavor and texture (WEEMAES et al., 1998). The application of a cooling process or refrigeration system for the storage after the fruit is harvested, in processed fruit and in fruit 'in natura', can also lead to a reduction in the activity of those enzymes (ARRUDA, 2002). 
Table 2. Enzymatic activity of soluble ionically bound POD and POD of Choquete variety avocado, in green and ripe maturation stages, at different temperatures $(\mathrm{T})\left(\mathrm{n}=3^{*}\right)$.

\begin{tabular}{|c|c|c|c|c|c|c|c|c|c|c|}
\hline $\mathrm{T}\left({ }^{\circ} \mathrm{C}\right)$ & 60 & 65 & 70 & 75 & 80 & 60 & 65 & 70 & 75 & 80 \\
\hline Time (minutes) & \multicolumn{10}{|c|}{ POD soluble $\left(\Delta \mathrm{DO}_{460 \mathrm{~nm} \min \mathrm{mL}}^{-1}\right)$} \\
\hline & \multicolumn{5}{|c|}{ Green stage } & \multicolumn{5}{|c|}{ Ripe stage } \\
\hline 0 & 2.960 & 2.960 & 2.960 & 2.960 & 2.960 & 2.880 & 2.880 & 2.880 & 2.880 & 2.880 \\
\hline 0,5 & 2.830 & 2.710 & 2.615 & 2.535 & 2.225 & 2.810 & 2.779 & 2.710 & 2.578 & 2.514 \\
\hline 1 & 2.710 & 2.599 & 2.554 & 2.471 & 2.120 & 2.760 & 2.701 & 2.605 & 2.501 & 2.467 \\
\hline 3 & 2.550 & 2.398 & 2.297 & 2.257 & 2.073 & 2.520 & 2.499 & 2.361 & 2.055 & 2.000 \\
\hline 6 & 2.360 & 2.140 & 2.015 & 2.000 & 1.891 & 2.380 & 2.233 & 2.115 & 1.814 & 1.713 \\
\hline 10 & 2.155 & 1.987 & 1.795 & 1.621 & 1.479 & 2.170 & 2.012 & 1.751 & 1.492 & 1.356 \\
\hline & \multicolumn{10}{|c|}{ ionically bound POD $\left(\Delta \mathrm{DO}_{460 \mathrm{~nm} \min \mathrm{mL}}{ }^{-1}\right)$} \\
\hline 0 & 3.010 & 3.010 & 3.010 & 3.010 & 3.010 & 3.200 & 3.200 & 3.200 & 3.200 & 3.200 \\
\hline 0,5 & 2.940 & 2.900 & 2.874 & 2.788 & 2.687 & 3.103 & 3.000 & 2.984 & 2.741 & 2.555 \\
\hline 1 & 2.870 & 2.810 & 2.802 & 2.722 & 2.611 & 2.876 & 2.760 & 2.696 & 2.599 & 2.500 \\
\hline 3 & 2.620 & 2.600 & 2.565 & 2.500 & 2.295 & 2.634 & 2.582 & 2.518 & 2.437 & 2.331 \\
\hline 6 & 2.415 & 2.399 & 2.316 & 2.058 & 2.000 & 2.420 & 2.354 & 2.242 & 2.171 & 2.001 \\
\hline 10 & 2.270 & 2.101 & 1.995 & 1.688 & 1.600 & 2.216 & 2.146 & 2.000 & 1.823 & 1.622 \\
\hline
\end{tabular}

${ }^{*} \mathrm{n}=$ replication number
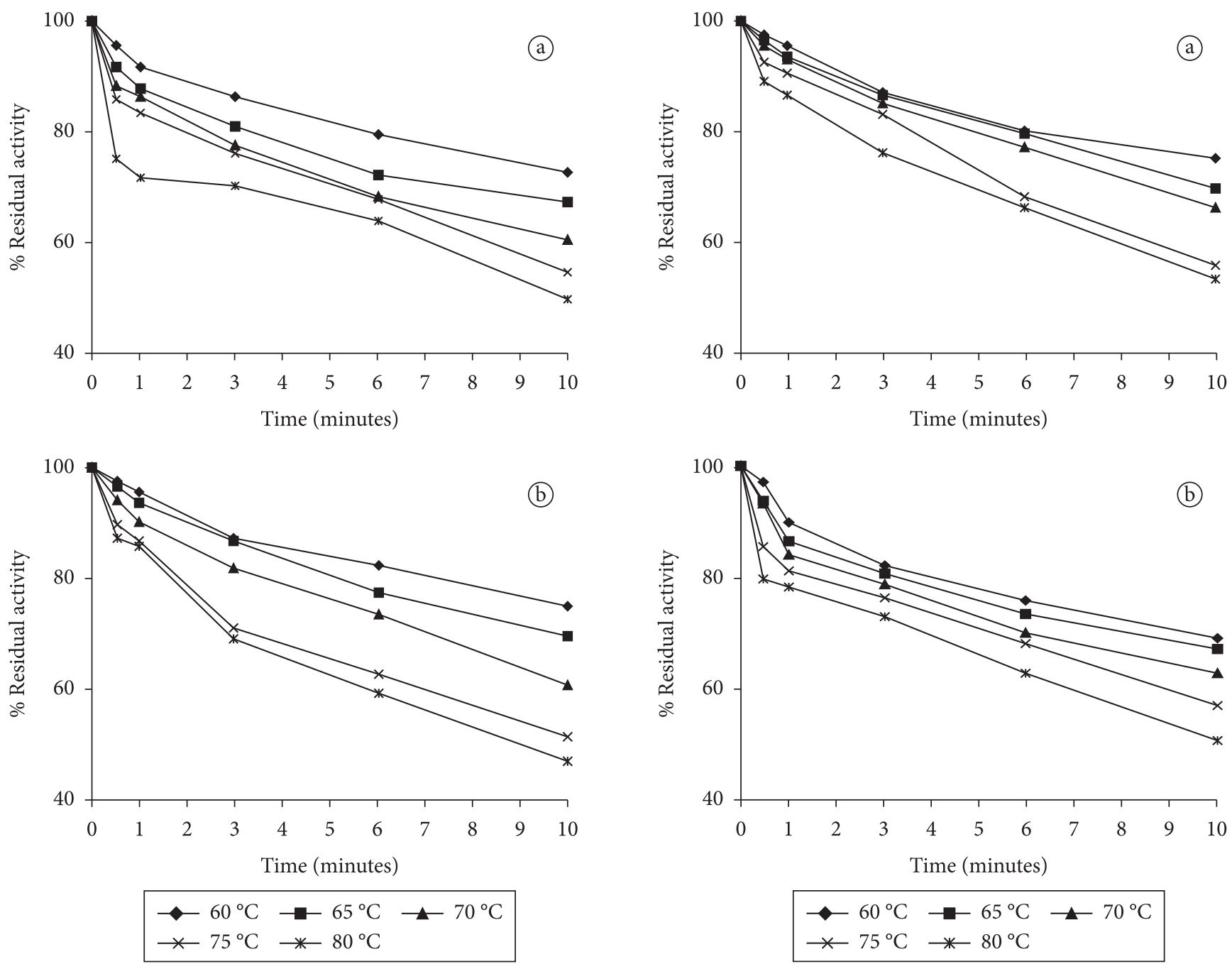

Figure 3. POD $\left(\Delta \mathrm{DO}_{460 \mathrm{~nm} m i n . \mathrm{mL}^{-1}}\right)$ Residual Activity of Choquete variety, in different temperature and different maturation stages: a) green, b) ripe.

Figure 4. Residual Activity of $\left(\Delta \mathrm{DO}_{460 \mathrm{~nm} \text { min.mL }}{ }^{-1}\right)$ ionically bound POD of the Choquete variety, in different temperature and different maturation stages: a) green, b) ripe. 


\section{Conclusions}

Among the avocado varieties analyzed, the Fortuna variety presented the lowest PPO enzymatic activity in its pulp in the ripe stage. Thus, the use Fortuna avocado variety for application in industrial processing is specially recommended compared to the other varieties. On the other hand, the Choquete variety presented the lowest POD activity in the green stage, and that value increased with climacteric fruit ripening.

\section{Acknowledgements}

The authors are grateful for the financial support provided by $\mathrm{CNPq}$ and to Sabino Leonides Moteka for supplying the avocado fruits.

\section{References}

ARAÚJO, J. M. A. Química dos alimentos. Viçosa: UFV, 1999.

ARRUDA, M. C. Processamento mínimo de melão rendilhado: tipo de corte, temperatura de armazenamento e atmosfera modificada. Piracicaba: ESALQ, 2002.

BRASIL. Ministério do Planejamento, Orçamento e Gestão. Instituto Brasileiro de Geografia e Estatística - IBGE. Produção agrícola municipal: culturas temporárias e permanentes. Rio de Janeiro, 2007. $69 \mathrm{p}$.

BRECHT, J. K. et al. Alterações metabólicas. In: MORETTI, C. L. Manual de processamento mínimo de frutas e hortaliças. Brasília: Embrapa Hortaliças, 2007. p. 41-77.

CANTO, W. L.; SANTOS, L. C.; TRAVAGLIN, M. E. M. Óleo de Abacate: extração, usos e sues mercados atuais no Brasil e na Europa. Campinas: ITAL, 1980.

CLEMENTE, E.; PASTORE, G. M. Peroxidase and polyphenoloxidase, the importance for food technology. Boletim da SBCTA, v. 32, n. 2, p. 167-171, 1998.

CLEMENTE, E. Purification and thermostability of isoperoxidase from oranges. Phytochemistry, v. 49, n. 1, p. 29-36, 1998.

FENEMA, O. R. Quimica de los alimentos. Zaragoza: Acribia, 1998.

FUJITA, S. et al. Purificación and properties of polyphenoloxidase from cabbage (Brassica oleracea L.). Journal Agriculture and Food Chemistry, v. 43, n. 5, p. 1138-1142, 1995.

GOMES, M. R. A. et al. Propriedades físico-químicas de polifenoloxidase de feijão (Phaseolus vulgaris L.). Ciência e Tecnologia de Alimentos, v. 21, n. 1 , p. $69-72,2001$.
HALPIN, B. et al. Purification and characterization of peroxidase from green peas. Journal of Food Science, v. 54, n. 3, p. 644-649, 1989.

LUIZ, R. C.; HIRATA, T. A. M.; CLEMENTE, E. Cinética da inativação da polifenoloxidase e peroxidase de abacate (Persea americana Mill.). Ciência e Agrotecnologia, v. 31, n. 6, p. 1763-1773, 2007.

MEDINA, J. C. et al. Abacate: da cultura ao processamento e comercialização. Campinas: ITAL, 1998.

MURASAKI, N. C. Cinética de inativação térmica peroxidase e polifenoloxidase presentes na água de coco verde por processo térmico contínuo. 2005. 78 p. Dissertação (Mestrado) Universidade de São Paulo, São Paulo, 2005.

PINELI, L. L. O.; MORETTI, C. L. Processamento mínimo de batata. In: MORETTI, C. L. Manual de processamento mínimo de frutas e hortaliças. Brasília: Embrapa Hortaliças, 2007. p. 343-363.

ROBINSON, D. S. Peroxidase and cabalase in food. In: ROBINSON, D. S.; SKIN, N. A. M. Oxidative enzymes in food. 1. ed. London: Elsevier, 1991. Cap 1, p. 1-48.

RUEDA-LUGO, U.; GONZÁLES-TENÓRIO, R.; TOTOSAUS, A. Substitución de lardo por grasa vegetal en salchichas: incorporación de pasta de aguacate, efecto de la inhibición del oscurecimiento enzimático sobre el color. Ciência e Tecnologia de Alimentos, v. 26, n. 2, p. 441-445, 2006.

SOLIVA-FORTUNY, R. C. et al.Kinetics of polyphenoloxidase activity inhibition and browning of avocado purée preserved by combined methods. Journal of Food Engineering, v. 55, n. 2, p. 131-137, 2002.

TANGO, J. S.; CARVALHO, C. R. L.; SOARES, N. B. Caracterização física e química de frutos de abacate visando a seu potencial para extração de óleo. Revista Brasileira de Fruticultura, v. 26, n. 1, p. 17-23, 2004.

TANGO, J. S.; TURATTI, J. M. Óleo de abacate. In: Abacate: cultura, matéria-prima, processamento e aspectos econômicos. Campinas: ITAL,1992. p. 156-192.

THÉ, P. M. P et al. Modificações na atividade enzimática em abacaxi 'Smooth Cayenne' em função da temperatura de armazenamento e do estádio de maturação. Ciência e Agrotecnologia, v. 25, n. 2, p. 364-370, 2001.

VALDERRAMA, P.; CLEMENTE, E. Isolation and thermostability of peroxidase isoenzymes from apple cultivars Gala and Fuji. Food Chemistry, v. 87, n. 4, p. 601-606, 2004.

WEEMAES, C. A. et al. Activity, eletrophoretic characteristicsand heat inactivation of polyphenoloxidases from apples, avocados, gapes, pears and plums. Technology, v. 31, n. 1, p. 44-49, 1998. 